\title{
The lost oasis: Archaeology of a 'forgotten' mikiri well in the Simpson Desert
}

\author{
Don Rowlands ${ }^{\mathrm{a}}$, Mike Smith ${ }^{\mathrm{b}, \mathrm{c},}$, Ingereth Macfarlane ${ }^{\mathrm{d}}$, Duncan Wright ${ }^{\mathrm{e}}$ and Max Tischler ${ }^{\mathrm{f}}$ \\ ${ }^{a}$ Queensland Parks and Wildlife Service, Birdsville, QLD 4482, Australia; ${ }^{\mathrm{b}}$ College of Humanities, Arts and Social

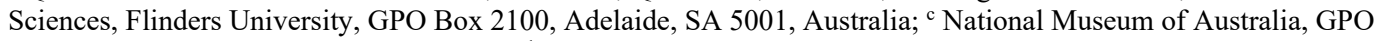 \\ Box 1901, Canberra, ACT 2601, Australia; d Aboriginal History Inc., Australian Centre for Indigenous History, \\ Research School of Social Science, The Australian National University, Canberra, ACT 2600, Australia; ${ }^{\text {e College of }}$ \\ Arts and Social Sciences, The Australian National University, Canberra, ACT 2600, Australia; ${ }^{\mathrm{f}}$ Australian Desert \\ Expeditions, 222A Barry Parade, Fortitude Valley, QLD 4006, Australia \\ *Corresponding author mike.smith@nma.gov.au
}

\begin{abstract}
This paper describes a previously unknown mikiri well in the Simpson dune field. This site was abandoned about 500-600 years ago and does not feature in ethnographic records for this region. We argue that its abandonment was most likely due to failure of the well caused by a fall in the local watertable. The Simpson Desert is one of the major sand-ridge deserts of the world, but current views of the chronology of human use of this vast dune field rest on only a handful of radiocarbon ages $(\mathrm{n}=12)$. The radiocarbon ages for this mikiri, and its surroundings, add to this limited dataset. We plot all available radiocarbon ages from archaeological sites in the dune field showing that occupation of this mikiri coincided with a widespread increase in use of the dune field during the last millennium, at about the time the Wangkanguru people in the dune field were becoming linguistically distinct from the Arabana to the west.
\end{abstract}

Places die, just as men do (Joubert, cited in Thesiger et al. 2000:102).

\section{Introduction}

The Simpson Desert is one of the great sand-ridge deserts of the world. Linear dunes run for more than $300 \mathrm{~km}$ in a roughly SSE-NNW parallel alignment, with individual dunes up to $26 \mathrm{~m}$ high. This vast dune field covers $176,500 \mathrm{~km}^{2}$ and is the driest part of the Australian arid zone. With mean annual rainfall around $100 \mathrm{~mm}$ per annum it is the only part of the Australian landmass that is hyper-arid. Wangkanguru occupation of this dune field was underpinned by a series of small desert wells, known as mikiri. Typically, these involved a narrow sloping shaft 6-7m deep to reach local ground water. The hydrology of these wells is not known in detail but they appear to depend on shallow local aquifers, where small bodies of potable water are present, perched above folds in a substrate of impermeable clay, gypcrete or calcrete.

In 1886, explorer David Lindsay visited nine of these wells with an Aboriginal guide (Lindsay 1886) at a time when people were still living in the dune field. Lindsay also recorded the names of several other mikiri that he did not visit. As the Wangkangurru left the dune field between 1890 and 1901 (Hercus 1985), other mikiri are known only by name, references in mythology (Hercus and Clark 1986; Reuther 1906; Strehlow 1970), or from an account given to Norman Tindale in 1934, that describes a walking route across the dune field from Pandie Pandie on Eyre Creek to Dalhousie Springs (a journey of $>14$ days with several waterless stages) (Tindale 1962). Altogether some 16-18 mikiri are known by name although not all have been relocated. For any others that are present in the dune field, we do not even have a name, and they have slipped from memory. The nine wells visited by Lindsay were relocated by Denis Bartell in the 1980s (Bartell 2012). Since then the locations of a further three mikiri Madlu, Puramaana and Yalkiri - have been determined.
The archaeology and mythology of the mikiri wells was subsequently described by Hercus and Clarke (1986) and by Smith and Clark (1993). Typically, the wells are surrounded by an arc of occupational debris, within $200-300 \mathrm{~m}$ of the well. This debris field commonly includes chipped stone artefacts, fragments of grinding stones and stone axes, and occasionally pieces of exotic baler shell. Most sites also have extensive scatters of faunal remains, including the bones of macropods and reptiles, pieces of freshwater mussel shell and of emu and bustard eggshell. It is also not uncommon to find wooden implements - such as corkwood shields, spear shafts, digging sticks and fragments of unidentified wooden implements as well as the remains of bough shelters. Postcontact items have been observed at several mikiri in the area, including a tea tin, steel chisel and a clay pipe (Hercus and Clarke 1986). The appearance of relatively recent occupation (c.1890-1901) is reinforced by the number of intact fireplaces, the relatively good condition of bone fragments, the presence of rabbit bones, and of ash (presumably prepared for consumption with bush tobacco) surviving on several of the grindstones.

Only two of the mikiri have previously been radiocarbon dated (Marapadi and Palkura) (Smith and Clark 1993) and there are few dates for occupation of the dune field or its immediate margins (Table 1). Current knowledge of the archaeology and human past of the dune field rests on a handful of studies (Barton 2003; Hamm et al. 2019; Hercus and Clarke 1986; Napton and Greathouse 1996; Ross and Smith 2009; Silcock et al. 2012; Smith 1988; Smith and Clark 1993; Smith and Ross 2007). The paucity of radiocarbon ages is a major impediment to reconstructing a detailed picture of human occupation in this vast dune field. The remoteness and difficulty of access of much of this area necessarily means that accumulation of radiocarbon data is a piecemeal process rather than the outcome of systematic field survey. In this context, serendipitous finds continue to play an important role. 
Table 1. Consolidated list of all radiocarbon dates currently available for the Simpson Desert. Dated material was charcoal from hearths, except in the case of Therreyererte where detrital wood charcoal from an archaeological deposit was dated. $\delta^{13} \mathrm{C}$ values are not reported for these samples.

\begin{tabular}{|l|l|l|l|l|l|}
\hline \multicolumn{1}{|c|}{ Site } & Lab. No. & \multicolumn{1}{|c|}{ Context } & \multicolumn{1}{|c|}{$\begin{array}{c}\text { Sample } \\
\text { Type }\end{array}$} & $\begin{array}{c}\text { Conventional } \\
\mathbf{1 4} \text { C Age } \\
\text { (years BP) }\end{array}$ & \multicolumn{1}{|c|}{ Reference } \\
\hline Marapadi & ANU-7683 & mikiri hearth & charcoal & $2710 \pm 130$ & Smith and Clark 1993 \\
\hline Palkura & ANU-7684 & mikiri hearth & charcoal & $200 \pm 80$ & Smith and Clark 1993 \\
\hline Kuncherinna & ANU-7520 & hearth on dune flank & charcoal & $1250 \pm 160$ & Smith and Clark 1993 \\
\hline Kuncherinna & ANU-7521 & hearth on dune flank & charcoal & $1000 \pm 70$ & Smith and Clark 1993 \\
\hline Oolgawa WH & ANU-2838 & hearth on dune flank & charcoal & $1900 \pm 200$ & Smith and Clark 1993 \\
\hline Oolgawa WH & ANU-2836 & hearth on dune flank & charcoal & $2220 \pm 100$ & Smith and Clark 1993 \\
\hline Oolgawa WH & ANU-2837 & hearth on dune flank & charcoal & $2840 \pm 80$ & Smith and Clark 1993 \\
\hline Therreyererte & SUA-2520 & occupation deposit & charcoal & $400 \pm 50$ & Smith 1988 \\
\hline Therreyererte & SUA-2519 & occupation deposit & charcoal & $1830 \pm 110$ & Smith 1988 \\
\hline Atnetye & Wk-30216 & occupation deposit & charcoal & $202 \pm 25$ & Smith 2010 \\
\hline Simpson Desert 275 & GX-14608 & buried hearth & charcoal & $1260 \pm 170$ & Napton and Greathouse 1996 \\
\hline Simpson Desert 275 & GX-14607 & buried hearth & charcoal & $275 \pm 70$ & Napton and Greathouse 1996 \\
\hline
\end{tabular}

In 2018, an Australian Desert Expeditions camel team exiting the dune field encountered a 'lost' mikiri about $100 \mathrm{~km}$ southwest of Birdsville, deep in the dune field $40 \mathrm{~km}$ west of Eyre Creek (Figures 1-2). This mikiri seems to have slipped from memory before Lindsay, Strehlow, Reuther, Tindale or Hercus made their records (see also Macfarlane 2010). In 2019, large floods along Eyre Creek and the Diamantina River interfered with the logistics of further scientific surveys by Australian Desert Expeditions in the dune field. This made it necessary to re-route several planned transects. At short notice, one of the redirected camel strings provided the opportunity for an archaeological team to record this lost mikiri (in June 2019), under the direction of DR - a senior Wangkangkuru man.

\section{Description of the 'Lost' mikiri}

The dominant feature of this site is a stand of large Corkwoods (Hakea eyreana) in a grove extending for $100 \mathrm{~m}$ along the western side of a swale. Corkwoods are associated with many of the known mikiri. In this open landscape this band of tall mature trees is highly unusual and is visible for some distance. Inter-dune swales more commonly support single-age groves of Gidgee (Acacia georgina) (up to 3-4m height) interspersed with claypans and areas of slope-wash. Altogether there are 26 large mature Corkwood trees at this site, which have a mean height of $6.58 \mathrm{~m}( \pm 0.71)$ with circumferences at chest height and canopy widths of $1.29 \mathrm{~m}( \pm 0.23)$ and $7.11 \mathrm{~m}( \pm 1.37)$ respectively. The size and persistence of these trees - which must be several hundred years old - indicates the presence of a pocket of local groundwater into which these trees have got their roots. On the margins of this zone, several other Corkwoods have seeded but then died because of the arid conditions. The presence of three recently dead red kangaroos (Megalia rufus) in this grove reflects the mobility of this species and its ability to disperse widely in search of forage. No actual well depression survives at this mikiri, although there are several depressions that may represent an old silted up well. This Corkwood grove is also notable for the presence of shrubs such as Acacia victoriae (a species widely used for its hard, edible seed), Senna artemisioides filifolia (known to host edible grubs in its roots), Enchlyaena tomentosa (known to have fleshy, edible fruits) and Eremophila longifolia (a plant known for its ritual importance in Central Australia (Latz 1995:176-177).

The main archaeological remains are on a sandy bench $(100 \mathrm{~m} \times 50 \mathrm{~m})$ immediately to the west of the Corkwoods. This relatively dense archaeological unit is a surface veneer above clean laminated sand. In this area chipped stone artefacts are abundant (10 lithics $\left./ \mathrm{m}^{2}\right)$ and heavily reduced with most flakes $<10 \mathrm{~mm}$ and most cores $<10 \mathrm{~g}$. Amorphous retouched artefacts are common but there are few formal flaked tools, other than two unworn semi-discoidal adzes in one location. Worn tula slugs - one of the most common artefacts in desert assemblages - are rare or absent at this site. No red ochre was found.

There is no local stone in this sector of the dune field so all stone must have been imported from some distance. The lithology of the flaked artefacts is varied and includes raw materials at the site from a variety of sources. The most common raw material is desert chalcedony - apparently from a worked outcrop $100 \mathrm{~km}$ to the northwest near Eyre Creek and a fine-grained grey/yellow silcrete, possibly from a gibber source just east of Eyre Creek, a minimum of $50 \mathrm{~km}$ away. Highly glossed - but unworked - pieces of brightly coloured red or yellow stone (5-20mm long) are common at this site. These sometimes occur in piles, and are most likely gizzard stones from a bird (see Cane 1982).

Fragments of grindstones $<10 \mathrm{~cm}$ (mainly fragments of millstones and topstones with occasional pieces of mortars) are abundant. All are broken. A range of indeterminate lithologies are present. Some are of the medium-grained pale sandstone characteristic of the famous Palthirri-pirdi quarry on Anna Creek in Arabana country on the western side of Lake Eyre (Hercus 2005). 


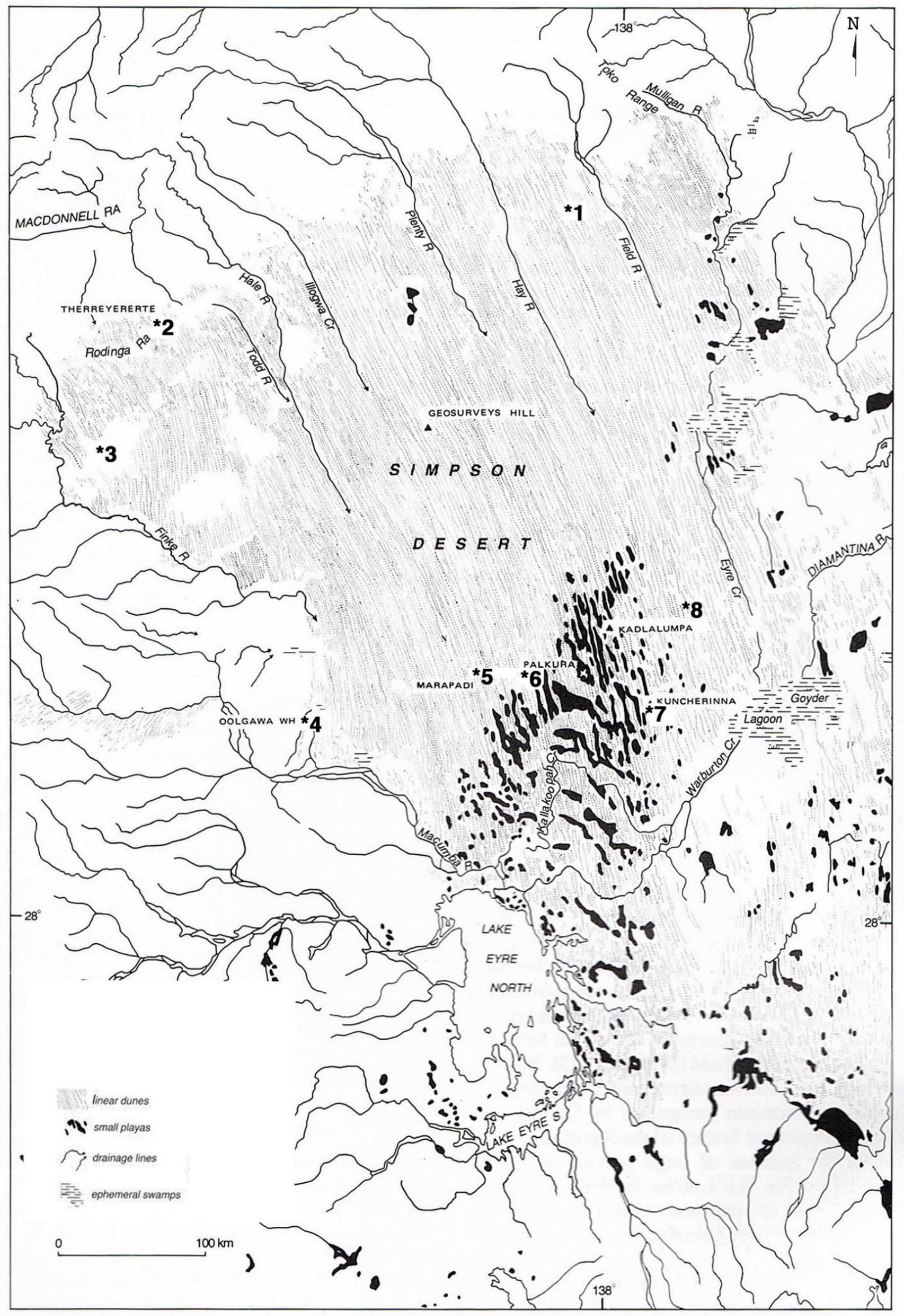

Figure 1. Map showing location of dated sites in the Simpson dune field. (1) Atnetye-Mt Knuckey, (2) Therreyererte, (3) Simpson Desert 275 and 276, (4) Oolgawa WH, (5) Marapadi, (6) Palkura, (7) Kuncherinna, and (8) The 'lost' mikiri. 
A single flake from a ground edge axe was noted but local evidence for the presence of these artefacts on the sandy bench is minimal. However, an intact 'greenstone' axe, of the dark igneous stone from the Mt Isa-Cloncurry axe quarries, was found on the flank of the dune to the west of the main site. Like other stone axes found in the dune field this axe had suffered major damage to the ground edge, which had been repaired by flaking as there is no local stone for regrinding the bevel.

Bleached and heavily fragmented animal bone is ubiquitous on the main site. Burnt bone is present but rare. Identifiable elements were rarely preserved and we found only two very fragmented mandibles. One is a right dentary fragment of Bettongia sp. (cf. lesueur) on the basis of $\mathrm{m} 1-\mathrm{m} 3$ and the alveoli of $\mathrm{m} 4$. The other is a dentary fragment (possibly RHS) of Dasyurus geoffroii, with roots of $\mathrm{m} 2$ and $\mathrm{m} 3$. The bettong is no surprise, as there appears to be an old warren system made up of low mounds of calcrete, to the south of this mikiri. The presence of the western quoll is unusual as there are relatively few records of this species in the Simpson dune field. Intact and relatively unabraded dentaries of agamid lizards, and mandibles of rabbits, form a modern surface float both among the grove of Corkwoods and on the archaeological surface.

Apart from this, there was an unexpected amount of burnt bird eggshell and fragments of freshwater mussel shell. The former is from a medium-sized bird presumably bush turkey (Australian Bustard) (Ardeotis australis) as the tracks of this bird were often noted during transects of the dune field. There was also at least one piece of emu eggshell (Dromaius novaehollandia) though this eggshell was rare at this site. The mussels are Velesunio sp. The quantity of mussel shell suggests that these were food items, which is not unlikely as Eyre Creek is only $40 \mathrm{~km}$ (one day's walk) away. Alternatively, they may have been brought in as tools (though no use-wear was observed) or as containers (though we did not detect any traces pf pituri or ochre on any of the pieces). Samples of burnt bustard eggshell and of Velesunio sp. shell, were collected for radiocarbon assay, and gave almost identical ages (ANU-20936 and ANU-20937) (Table 2) indicating that the latest phase of occupation at this mikiri was around 600 years ago (534-634 and 547-644 cal BP). Survey with a metal detector confirmed that there were no European items on this site.

We noted several features in the vicinity of the Corkwoods, though none survived on the bench itself:

1. A claypan dam. This is a linear feature, now no more than an earthen bank 10-15cm-high, $20 \mathrm{~cm}$-wide, and $4 \mathrm{~m}$-long. This bisects a claypan, intersecting surface flow on a pan with a gentle slope.

2. A human burial is present within $100 \mathrm{~m}$ of the main occupation surface. This is a young adult, buried in a supine position, with head to the south.

3. We also noted an isolated hearth at the base of a neighbouring sand ridge $500 \mathrm{~m}$ east of the site. This was a large patch of charcoal $(60 \mathrm{~cm} \times 40 \mathrm{~cm})$ on a low residual of indurated sand, with finely cominuted charcoal and burnt bone.



Figure 2. Australian Desert Expeditions camel string, June 2019, Simpson dune field (Photograph: M.A. Smith).

\section{The Surrounding Debris Field}

The paucity of artefacts in the dune field contrasted with their abundance in the vicinity of the mikiri (Figure 3). The Australian Desert Expeditions camel transects allowed $\sim 14 \mathrm{~km}^{2}$ to be searched in a large arc of dune field surrounding the mikiri.

At $>5 \mathrm{~km}$ from the mikiri, there is a low background density of stone artefacts $\left(<1 / 200 \mathrm{~m}^{2}\right)$. These were mostly small heavily reduced artefacts of grey/yellow silcrete or of desert chalcedony.

At $<5 \mathrm{~km}$ from the mikiri, we found many more stone artefacts $\left(\sim 1 / 50-100 \mathrm{~m}^{2}\right)$ in an arc of debris mostly in the same dune swale north of the mikiri and with lower densities to the southwest and east (Figure 3). This scatter of debris included another ground-edge axe, with its edge repaired by flaking, as well as large fragments of millstones, complete mullers and other topstones, and several mortars on quartzite blocks. The artefacts north of the mikiri include many pieces of broken grinding base plates, much larger than the fragments surviving on the mikiri. Many of the grindstones were either intact mullers or pieces of broken millstones that had been recycled as base plates in their own right. Most were of the distinctive pale Anna Creek sandstone. In all cases, the original blanks had been extensively hammer-dressed.

To the east of the mikiri, in the next swale, we found a discrete scatter of much larger lithics than was usual in this dune field, or at the mikiri itself. These included silcrete flakes up to $4 \mathrm{~cm}$ long and a relatively large platform core $\sim 400 \mathrm{~g}$. Apart from this there was relatively little material to the east of the mikiri. 
Table 2. Radiocarbon ages in this study. Calibrated age spans are reported at $95.4 \%$ probability using the southern hemisphere calibration curve (Hogg et al. 2013) and CALIB REV7.1.0 (Stuiver and Reimer 1993). An AMS derived $\delta^{13}$ C was used by the ANU radiocarbon laboratory to calculate the age estimates.

\begin{tabular}{|c|l|l|l|c|}
\hline Lab. No. & \multicolumn{1}{|c|}{ Context } & \multicolumn{1}{|c|}{ Sample Type } & $\begin{array}{c}\text { Conventional } \\
{ }^{14} \text { C Age } \\
\text { (years BP) }\end{array}$ & $\begin{array}{c}\text { Calibrated Age BP 95.4\% } \\
\text { (probabilities) }\end{array}$ \\
\hline ANU-20936 & mikiri occupation deposit & Velesunio sp. & $622 \pm 25$ & $534-634$ \\
\hline ANU-20937 & mikiri occupation deposit & eggshell (possibly Ardeotis australis) & $644 \pm 23$ & $547-644$ \\
\hline ANU-63309 & hearth on dune flank (IM-1) & charcoal & $1253 \pm 27$ & $1028-1259$ \\
\hline
\end{tabular}

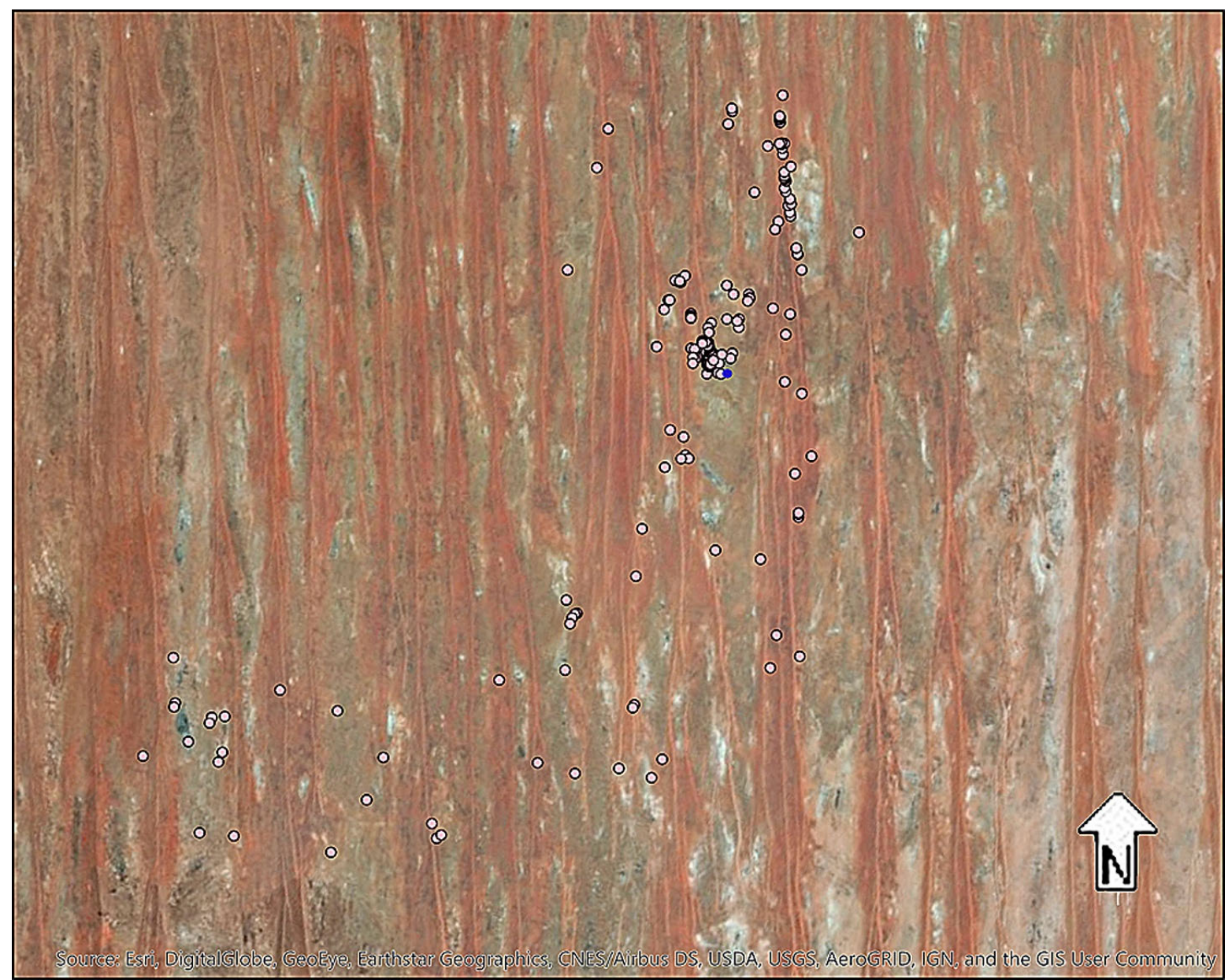

Figure 3. Distribution of stone artefacts (lithics, grindstones and ground-edge artefacts (pink dots) in this part of the Simpson dune field showing a concentration of artefacts around the mikiri (blue dot) and a scatter of artefacts in a corridor to the north. Scale: width of this image is $\sim 15 \mathrm{~km}$.

\section{Dated Hearth}

We found a more ancient hearth (IM-1) $7-10 \mathrm{~km}$ southwest of the mikiri. This was on a low residual in indurated clayey and calcareous dune sand on the lower flank of a sand ridge, where it was exposed by sheet wash and local erosion.

IM-1 was a diffuse oval feature $40 \mathrm{~cm} \times 30 \mathrm{~cm}$ with abundant finely comminuted charcoal and many larger pieces of charcoal. Sampling showed it was some $10 \mathrm{~cm}$ deep and possibly plano-convex, though the pace of travel with the camel teams did not allow more detailed investigation of its structure. No micro-fragments of any cultural material were present (such as baked clay, shell, burnt bone, fine stone chips) but the absence of detrital charcoal in this landscape made it an unusual find. Downslope, on the eroded area, there was a localised scatter of lithics, mostly of fine-grained grey/yellow silcrete, including two tula adze slugs. The apparent association with these lithics suggested that this hearth was a late Holocene feature, but its stratigraphic context indicated somewhat greater antiquity than the majority of material at the mikiri, or elsewhere in the transect. Radiocarbon assay of the hearth (ANU-63309) gave an age of 1253 BP (1028-1259 cal BP) (Table 2). 


\section{Discussion}

Our evidence indicates that the last use of this 'lost' mikiri dates around 600 years ago, well before the colonial period, and somewhat earlier than the last phase of occupation at the known mikiri. At this mikiri, the surviving traces of occupation are more weathered compared with those at other mikiri, with highly reduced and fragmented artefacts, poor preservation of surviving bone fragments, few intact features such as hearths, no surviving wooden implements or huts, and no clear well depression.

There is also no memory of its name or (as far as we are aware) an associated mythology. Despite its proximity to Eyre Creek, there are no pieces of metal artefacts. This is a mikiri that was abandoned well before the $1870 \mathrm{~s}$. Although such a prominent copse of large trees must have some place in a contemporary totemic landscape we could detect no evidence of recent Wangkangurru visits to the site. Whatever the case, our radiocarbon ages support the interpretation that this is a fully pre-European site and that the well has not been used for some 600 years. This mikiri seems to have slipped from memory before Lindsay, Strehlow, Reuther, Tindale or Hercus made their records.

Our investigation of the surrounding landscape suggest that the major seed stands and seed-grinding areas were along the swale just to the north of the mikiri. This proposition is corroborated by the relative abundance of grasses in this locale (including Eragrostis spp.).

The pattern of debris in the dune field, and the prevalence of desert chalcedony amongst the lithics, also suggests that people primarily accessed this mikiri from the north. This supports a pattern of movement in which people travelled from other mikiri - such as Yalkiri and Puramana - that are within a couple of days walk to the north. The discard of relatively large artefacts, in one locality east of this mikiri, also suggests that its inhabitants occasionally travelled due east directly to Eyre Creek where they could replenish their supply of silcrete.

The wide range of lithologies - particularly Anna Creek sandstone and Mt Isa-Cloncurry volcanics testifies to the long-distance exchange links of people in the dune field, whether or not they acquired these materials by down-the-line exchange or by trade or direct procurement.

Although it is not certain as to why this desert well was abandoned, we speculate that a falling water-table after 600 BP placed local ground-water at a depth beyond the reach of a narrow well shaft. The presence of single-age stands of Gidgee and Corkwood (both possibly several centuries old, with no recent recruitment of saplings) suggests some decline in local rainfall around this time. If this did occur it would have changed the extent to which the local aquifer was replenished. This was clearly only a local impact - and not a widespread general decline in desert groundwater in the dune field - as other mikiri wells continued to be viable and were occupied into the contact period. The presence of an earth dam at this mikiri might point to attempts to extend the availability of water at this site even as the well failed.

A summed probability plot of all available radiocarbon dates $(n=15)$ for the Simpson dune field (Figure 4) shows that occupation of this mikiri occurred during a widespread increase in use of the dune field during the last millennium, at about the time the people in the dune field were becoming linguistically distinct from the Arabana to the west (Hercus 1994). ANU63309 (1028-1259 cal BP) indicates that people were visiting this locality around 1200 years ago. However, several dates also show there was some use of the dune field, its mikiri, and the western margins of the dune field closer to the flood-out of the Finke River, as early as 2000-3000 BP (Table 1), well before classic Wangkangurru occupation of this region took shape. At present there are too few data to indicate the nature of this earlier use, although localities with mikiri were sometimes targets for these visits. We could reasonably expect to find evidence of earlier use of this arid dune field region during the wetter climate of the early Holocene 6-10 ka (Hesse et al. 2004), and we expect that current data incorporate a strong taphonomic signal, as these landscapes are too active geomorphically to make the search for earlier sites a straightforward task. For example, we note that there are few exposures of the older consolidated sediments that make up dune-cores in the Simpson dune field.



Figure 4. Summed probability plot of ${ }^{14} \mathrm{C}$ age frequencies for the Simpson Desert ( $n=15$ radiocarbon ages). Occupation of the 'lost' mikiri coincides with an apparent peak in occupation of the dune field during the last millennium. 


\section{Conclusion}

Whenever use of this 'lost' mikiri was initiated, it seems likely that failure of the well after $600 \mathrm{BP}$ led to its abandonment several centuries before the impact of European activities in the Eyre Creek area on the margin of the dune field. The story of this mikiri adds to the sparse corpus of archaeological data about the human history of the vast Simpson dune field.

\section{Acknowledgements}

Our title is a reference to the desert classic by Ahmed Hassanein Bey, The Lost Oases (1925), a book that deals with a forgotten oasis, and its archaeology, in the Saharan dune field, west of the River Nile. This was also finally relocated during a long camel trip. Our work was undertaken as part of a program of scientific and ecological surveys by Australian Desert Expeditions. The authors thank Andrew Harper for the opportunity to walk the dune field with his camel strings. Radiocarbon dates were supported by the Australian National University and DW. No other funding was involved in this work. We thank our travelling companions who assisted in transect recording, and our calm, unflappable cameleers - Daniela Bradley, Ann Hamilton and Sam Pincott. MAS, IM, DW and MT also thank Don Rowlands for his encouragement of this venture and his deep interest in the history and geography of the dune field. We thank Alex Baynes for expert identification of the two mandibles, Alan Williams for assistance with Figure 4, and Nicholas Skopa for constructing the artefact plots shown in Figure 3.

\section{References}

Barton, H. 2003 The thin film of human action: Interpretations of arid zone archaeology. Australian Archaeology 57:32-41. https://doi.org/10.1080/03122417.2003.11681760

Bartell, D. 2012 Desert Walker: My Adventures Relived. Banksia Beach, QLD: Denis Bartell.

Cane S. 1982 Bustard gastroliths in the archaeological record. Australian Archaeology 14:25-34.

Hamm, G., D. Rowlands and M. Smith 2019 Frontier mystery: An unusual mound of kopi mourning caps on the eastern edge of the Simpson Desert. Queensland Archaeological Research 22:59-63. https://doi.org/10.25120/qar.22.2019.3700

Hassanein Bey, A.M. 1925 The Lost Oases. London: Thornton Butterworth.

Hercus, L. 1985 Leaving the Simpson Desert. Aboriginal History 9(1):22-43. https://doi.org/10.22459/AH.09.2011.02

Hercus, L. 1994 A Grammar of the Arabana-Wangkangurru Language, Lake Eyre Basin, South Australia. Pacific Linguistics Series C-128. Canberra: Research School of Pacific and Asian Studies, Australian National University.

Hercus, L. 2005 A hole in the ground and a quarry. In I. Macfarlane (ed.), Many Exchanges: Archaeology, History, Community and the Work of Isabel McBryde, pp.185-198. Aboriginal History Monograph 11. Canberra: Aboriginal History Inc.

Hercus, L. and P. Clarke 1986 Nine Simpson Desert wells. Archaeology in Oceania 21(1):51-62. https://doi.org/10.1002/ j.1834-4453.1986.tb00124.x

Hesse, P.P., J.W. Magee and S. van der Kaars 2004 Late Quaternary climates of the Australian arid zone: A review. Quaternary International 118-119:87-102. https://doi.org/10.1016/S1040$\underline{6182(03) 00132-0}$
Hogg, A.G., Q. Hua, P.G. Blackwell, M. Niu, C.E. Buck, T.P. Guilderson, T.J. Heaton, J.G. Palmer, P.J. Reimer, R.W. Reimer, C.S. Turney and S.R.H. Zimmerman 2013 SHCal13 Southern Hemisphere calibration, 0-50,000 years cal BP. Radiocarbon 55(4):1889-1903. https://doi.org/10.2458/azu is rc.55.16783

Latz, P. 1995 Bushfires and Bushtucker: Aboriginal Plant Use in Central Australia. Alice Springs: IAD Press.

Lindsay, D. 1886 Field Notes of a Kourney [4-23 January 1886] from Dalhousie Station to Latitude $25^{\circ} 30^{\prime}$ on the Queensland Boundary. Unpublished manuscript, South Australian State Records, GRS 1/162 (1886), Adelaide [see also Royal Geographical Society of South Australia, Manuscript, D.R 21/36].

Macfarlane, I.A.S. 2010 Entangled Places - Interactional History in the Western Simpson Desert, Central Australia. Unpublished PhD thesis, Australian National University, Canberra.

Napton. L.K. and E.A. Greathouse 1996 Archaeological investigations in the Simpson Desert, Northern Territory. In P. Veth and P. Hiscock (eds), Archaeology of Northern Australia: Regional Perspectives, pp.106-136. Tempus 4. St Lucia, QLD: Anthropology Museum, University of Queensland.

Reuther, J.G. 1906 The Diari [Translated by PA Scherer 1981]. AIAS Microfiche No. 2. Canberra: Australian Institute of Aboriginal Studies.

Ross, J. and M.A. Smith 2009 An engraved 'archaic face' in the northeastern Simpson Desert. Australian Archaeology 69:68-70. https://doi.org/10.1080/03122417.2009.11681902

Silcock, J.L., M. Tischler and M.A. Smith 2012 Quantifying the Mulligan River pituri, Duboisia hopwoodii ((F. Muell.) F.Muell.) (Solanaceae), trade of central Australia. Ethnobotany Research and Applications 10:37-44. https://doi.org/10.17348/era.10.0.037-044

Smith, M.A. 1988 The Pattern and Timing of Prehistoric Settlement in Central Australia. Unpublished PhD thesis, University of New England: Armidale.

Smith, M.A. and P. Clark 1993 Radiocarbon dates for prehistoric occupation of the Simpson Desert. Records of the South Australian Museum 26(2):121-127.

Smith, M.A. and J. Ross 2007 A reinvestigation of the archaeology of Geosurveys Hill, northern Simpson Desert. Australian Archaeology 64:50-52. https://doi.org/10.1080/03122417.2007. $\underline{11681849}$

Strehlow, T.G.H. 1970 Geography and the totemic landscape in Central Australia: A functional study. In R.M. Berndt (ed.), Australian Aboriginal Anthropology, pp.92-140. Nedlands, W.A.: University of Western Australia Press.

Stuiver, M. and P.J. Reimer 1993 Extended ${ }^{14} \mathrm{C}$ data base and revised CALIB 3.0 14C calibration program. Radiocarbon 35(1):215-230. https://doi.org/10.1017/S0033822200013904

Thesiger, W., R. Depardon, M. Khemir and P. Virilio 2000 The Desert. New York: Thames and Hudson.

Tindale, N.B. 1962 Native Route across the Arunta Desert. Unpublished manuscript, South Australian Museum, SAM AA 338/1/24 Journal of Field work in and near the Simpson Desert (Arunta Desert) Central Australia. Adelaide.

Citation: Rowlands, D., M. Smith, I. Macfarlane, D. Wright and M. Tischler 2020 The lost oasis: Archaeology of a 'forgotten' mikiri well in the Simpson Desert. Queensland Archaeological Research 23:1-7. https://doi.org/10.25120/qar.23.2020.3717 